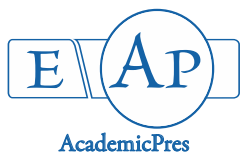

Çetinbaş-Genç A and Ünal M (2021)

Notulae Scientia Biologicae

Volume 13, Issue 2, Article number 10911

DOI: $10.15835 / \mathrm{nsb} 13210911$

Research Article

\title{
Apomictic development during different flower development stages in Crataegus tanacetifolia (Lam.) Pers., endemic to Turkey
}

\author{
Aslıhan ÇETINNBAŞ-GENÇ*, Meral ÜNAL
}

Marmara University, Department of Biology, Göztepe Campus, 34730 Istanbul, Turkey;

aslihan.cetinbas@marmara.edu.tr ("${ }^{*}$ corresponding author); meral.unal@marmara.edu.tr

\begin{abstract}
In this study, aposporic apomictic development and its relation to the different flower development stages were investigated by light and fluorescence microscopy in Crataegus tanacetifolia (Lam.) Pers. (Rosaceae). At pre-anthesis stage, aposporic initial cell differentiated at the somatic nucellus tissue shortly after the megaspore mother cell formation. The volume of aposporic initial cell increased during the generation of dyad and megaspore tetrad respectively by regular meiosis. At this stage, linear megaspore tetrad and vacuolated aposporic initial cell were located side by side into the same ovule. At anthesis stage, before pollination, four nucleated aposporic embryo sac was formed while sexual development came to end by atrophy of megaspores completely. At this stage, atrophied megaspores and two nucleated aposporic embryo sac were located side by side into the same ovule. At post-anthesis stage, pollination still had not begun and ovule contained only eight nucleated aposporic embryo sac. Mature aposporic embryo sac was composed of two synergid cells and one egg cell on the micropylar side, three antipodal cells on the chalazal side and a central cell with two polar nuclei in the middle of the sac. The absence of filiform apparatus in the synergid cells was quite remarkable. No callose accumulation around the aposporic initial cell was observed in any development stage. Pollination started shortly after the proembryo formation. Embryo and endosperm developed without fertilization due to the problems encountered in reaching pollen tubes to the ovary.
\end{abstract}

Keywords: apomixis; apospory; flowering time; pollination time; Rosaceae

\section{Introduction}

Crataegus tanacetifolia (Lam.) Pers. is an important endemic species to Turkey and, belongs to subfamily Maloideae of Rosaceae (Campbell et al., 2007; Uzun and Kaya, 2016). Apomixis is a common reproductive strategy in family Rosaceae (Khan et al., 2015). It has been identified in more than 120 genera of angiosperms and reported in 100 taxa of subfamily Maloideae (Robertson et al., 2010; Khan et al., 2015). Apomixis is the ability of a plant to pass through the essential steps (meiosis and fertilization) of the sexual reproduction to produce fertile seeds (Tang et al., 2016; Hojsgaard and Hörald, 2019). It is divided into 3 subtypes based on the origin of embryo-forming cells i.e. apospory, diplospory and adventive embryony (Priyadarshan, 2019; Zhang et al., 2020). Most apomictic plants belonging to the subfamily Maloideae follow the aposporic model and, embryo sac with unreduced nuclei is formed by somatic nucellar cell (Musial and Koscinska-Pajak, 2013). In contrast to sexually reproducing plants, most apomictic plant is not required to be

Received: 18 Feb 2021. Received in revised form: 25 Mar 2021. Accepted: 29 Apr 2021. Published online: 05 May 2021.

From Volume 13, Issue 1, 2021, Notulae Scientia Biologicae journal uses article numbers in place of the traditional method of continuous pagination through the volume. The journal will continue to appear quarterly, as before, with four annual numbers. 
fertilized for embryo formation. Generally, fertilization of the polar nuclei is necessary for endosperm formation in most apomictic plants, but the endosperm develops autonomously in some apomictic plants (Kumar, 2017).

Although apomixis is a genetically controlled mechanism, researchers have put forward various opinions about the underlying reasons why a plant chooses the apomictic reproduction. It has been thought that the species choose the apomictic reproductive pattern due to the developmental delays in female gametogenesis and, the problems encountered during sperm entry into the embryo sac (Yao et al., 2007). Also, delays in embryo sac development and the absence of the filiform apparatus, that necessary for pollen tube entrance into the embryo sac, have been associated with apomixis (Koscinska-Pajak and Bednara, 2006). Besides, it has been suggested that callose plays a key role in determining the reproductive strategy due to the differentiation of the callose accumulation pattern in the ovule of sexual and apomictic plants (Galla et al., 2011; Musial et al., 2015). Many concrete studies have been conducted and presented to support these ideas. Except for these ideas, researchers have suggested that flowering and pollination time have a decisive influence on reproductive strategy (Liu et al., 2014).

In this study, the apomictic developmental model of $C$. tanacetifolia was elucidated with all the details. Apomictic development was examined parallelly with different flower development stages, and whether flowering and pollination time affected apomictic development. Our results could provide useful data for understanding the relationship between flower developmental stages with apomictic development and, could improve the information about the apomictic development pattern in plants.

\section{Materials and Methods}

\section{Plant material}

Flowers of Crataegus tanacetifolia (Lam.) Pers. were sampled from natural habitats within the borders of Bolu, Lake Abant Nature Park (Turkey). Flowers were selected from at least 10 healthy trees of same population and different developmental stages of flowers were determined by stereomicroscope (Olympus 970931). After determination of different developmental stages, flowers were fixed in formalin-glacial acetic acid-alcohol solutions ( $40 \%$ formalin, glacial acetic acid, 100\% alcohol and distilled water at 10:5:50:35 by volume) (Sass,1958), embedded in paraffin and cut at 5-8 $\mu \mathrm{m}$ by Leica RM2235 rotation microtome. For each developmental stage, at least 20 flowers were studied.

\section{Light microscopy}

Sections were stained with Delafield's hematoxylin for general structures, Coomassie Brillant Blue (CBB) for proteins (Fisher et al., 1968), and Periodic-Acid Schiff (PAS) for insoluble polysaccharides (Feder and O'Brien, 1968). Preparations were photographed with KAMERAM colour camera and attached to Olympus BX-51light microscope. Images were analysed though KAMERAM scientific image processing and analysis software.

\section{Fluorescence microscopy}

Sections were stained with Aniline Blue for callose accumulation (Kenrick and Knox, 1985) and 4',6diamidino-2-phenylindole (DAPI) for nucleus disorders (Schweizer, 1976). Preparations were investigated by Olympus BX-51 fluorescence microscope at respectively $455 \mathrm{~nm}$ and $365 \mathrm{~nm}$ wavelengths and, photographed by KAMERAM fluorescence camera. 


\section{Results}

\section{Determination of developmental stages}

Flower development was divided into three successive stages (pre-anthesis, anthesis, and post-anthesis) correlated with some morphological markers such as colour, the position of calyx and corolla, anther dehiscence, and the absence or presence of pollen on the stigma. In the stage of pre-anthesis, flower buds were ovoid with calyx covering half or all the bud. At the anthesis stage, flowers were fully opened with their elongated petals. Although flowers were at the anthesis stage, there were no pollen grains on the stigma, because the anthers were still indehiscent. At the post-anthesis stage, the colour of the petals turned to brown, however, anthers were still indehiscent and there were no pollen grains on the stigma. Embryo sac development were investigated parallelly with pre-anthesis, anthesis and post anthesis stages. Pre-anthesis, anthesis, and postanthesis stages were also referred as the pre-pollination stages due to the pollination did not begun. The stages in which pollen grains were seen on the stigma were referred as the pollination stage. Embryo and endosperm formation were investigated parallelly with pre-pollination and pollination stages.

\section{Formation of sexual and apomictic embryo sacs}

In early stage of ovule development, concomitant with the differentiation of integuments, an archesporial cell differentiated and developed directly into the megaspore mother cell (MMC) (Figure 1a). Shortly after the MMC formation, an aposporic initial cell with a big nucleus and dense cytoplasm differentiated at the somatic nucellus tissue that adjacent to the chalazal side of the MMC (Figure 1b). It was determined that usually two aposporic initial cells differed (Figure 1b). While MMC generated dyad and megaspore tetrad respectively by regular meiosis, the volume of aposporic initial cell increased and, a large vacuole was formed within the cell. At this stage, linear megaspore tetrad and vacuolated aposporic initial cell were located side by side into the same ovule (Figure 1c). In this stage, flowers were at pre-anthesis and, anthers contain microspore tetrads indicating that microsporogenesis and megagametogenesis were performed simultaneously.

During further development, aposporic initial cell gave rise two nucleated aposporic embryo sac by mitosis (Figure 1d). The nuclei of megaspore tetrad began to atrophy and, atrophied megaspores and two nucleated aposporic embryo sac were located side by side into the same ovule (Figure 1e). In this stage, although the flowers were at anthesis, pollination did not start. While the second mitotic division resulted in four nucleated aposporic embryo sac, the sexual development came to end by atrophy of megaspores completely (Figure 1f). In this stage, although the flowers were still at anthesis, they had not entered the pollination stage.

As a result of the third mitosis, while the eight nucleated aposporic embryo sac was formed, the ovule took its final shape and became anatropous (Figure $1 \mathrm{~g}$ ). The ovule contained only eight nucleated aposporic embryo sac at this stage (Figure 1h). Although flowers had entered the post-anthesis, pollination did not start yet. It was determined that although usually two aposporic initial cells differed, but only one of them formed a mature aposporic embryo sac. However, rarely two aposporic initial cells developed and two mature aposporic embryo sacs (4\%) occurred. In such cases, the aposporic initial cells usually developed synchronously and, mature aposporic embryo sacs became almost the same size (Figure 1i).

Mature aposporic embryo sac was composed of two synergid cells and one egg cell on the micropylar side, three antipodal cells on the chalazal side and a central cell with two polar nuclei in the middle of the sac. The absence of filiform apparatus in the synergid cells was quite remarkable (Figure 1h). The cells of nucellus cap had low content of organic matter and, obturator was non-secretory (Figure 1g). 

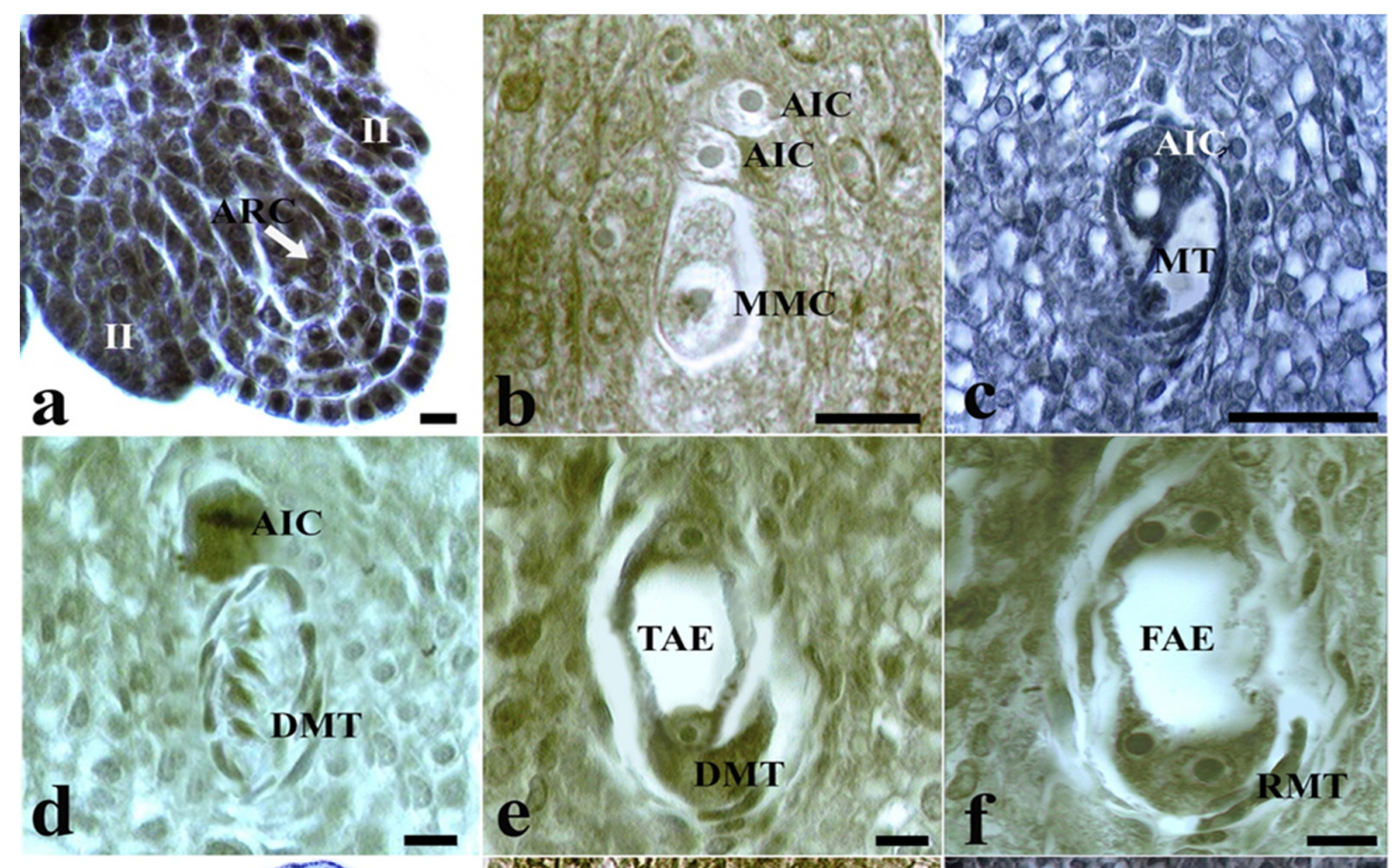

TAE

FAE
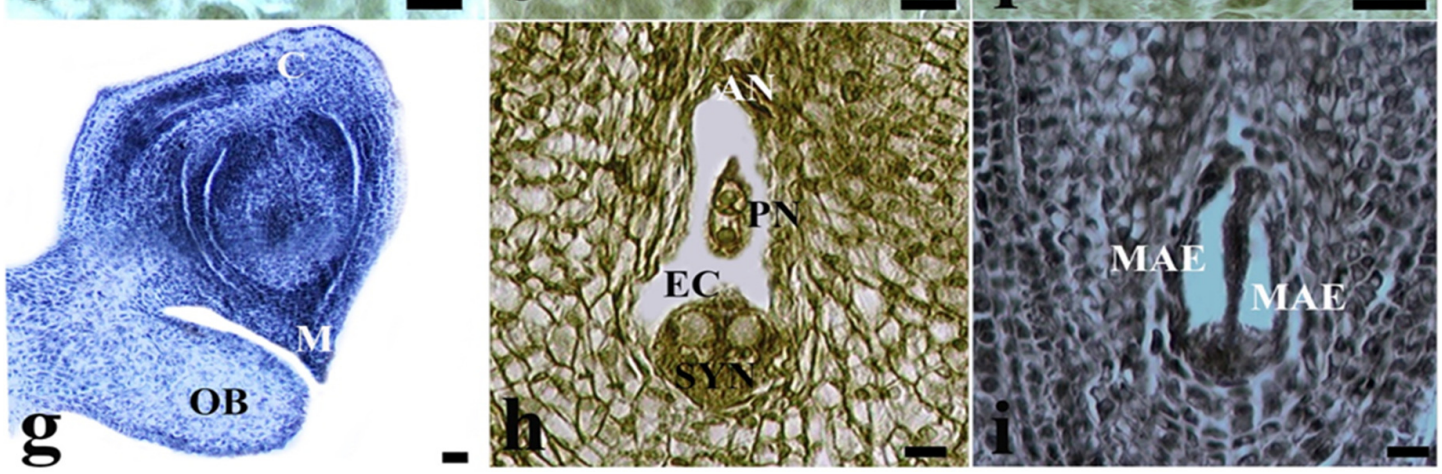

Figure 1. Sexual and apomictic embryo sac formation in C. tanacetifolia

a Archesporial cell, b Megaspore mother cell and aposporic initial cells, $\mathbf{c}$ Vacuolated aposporic initial cell and linear megaspore tetrad, $\mathbf{d}$ Metaphase at first mitosis of aposporic initial cell and degeneration of megaspore tetrad, $\mathbf{e}$ Two nucleated aposporic embryo sac and degenerating megaspore tetrad in the same ovule, $f$ Four nucleated aposporic embryo sac and the remnant of megaspore tetrad, $\mathbf{g}$ Mature anatropous ovule, $\mathbf{h}$ Eight nucleated mature aposporic embryo sac, $\mathbf{i}$ Two mature aposporic embryo sac in a mature ovule. ARC: Archesporial cell, II: Inner integument, AIC: Aposporic initial cell, MMC: Megaspore mother cell, MT: Megaspore tetrad, TAE: Two nucleated aposporic embryo sac, DMT: Degenerated megaspore tetrad, FAE: Four nucleated aposporic embryo sac, RMT: Remnant of megaspore tetrad, OB: Obturator, C: Chalaza, M: Micropyle, AN: Antipodal cell, PN: Polar nuclei, EC: Egg cell, SYN: Synergids, MAE: Mature aposporic embryo sac. Bar: $10 \mu \mathrm{m}$.

The developmental processes of sexual and aposporic embryo sac were investigated comparatively with the flower development stages and presented in Table 1. 
Table 1. The comparison of sexual and aposporic embryo sac development with different flower developmental stages in C. tanacetifolia

\begin{tabular}{|l|c|c|}
\hline \multirow{2}{*}{$\begin{array}{c}\text { Development } \\
\text { stage }\end{array}$} & $\begin{array}{c}\text { Sexual embryo } \\
\text { Sac development }\end{array}$ & $\begin{array}{c}\text { Aposporic embryo } \\
\text { Sac development }\end{array}$ \\
\hline \multirow{3}{*}{ Pre-anthesis } & Differentiation of archesporial cell & ----- \\
\cline { 2 - 3 } & Differentiation of MMC & Differentiation of aposporic initial cell \\
\cline { 2 - 3 } & Dyad formation & Vacuolization of aposporic initial cell \\
\cline { 2 - 3 } Anthesis & Megaspore tetrad formation & Vacuolization of aposporic initial cell \\
\cline { 2 - 3 } & Completely degeneration of megaspore tetrad & Two nucleated aposporic embryo sac \\
\hline \multirow{2}{*}{ Post-anthesis } & $-\cdots---$ & Fight nucleated mature aposporic embryo \\
& & sac \\
\hline
\end{tabular}

\section{Callose depositions during formation of sexual and apomictic embryo sacs}

Callose was initially clearly detectable at the chalazal pole of MMC as a crescent-like band (Figure 2a) and then completely surrounded the cell (Figure $2 \mathrm{~b}$ ). It indicated that development of Polygonum type sexual embryo sac, which functional megaspore occurred at the chalazal pole. However, without active megaspore was determined, the sexually developing embryo sac was atrophied. During dyad and tetrad stage, callose was principally located as a thick plate on the transverse wall separating each of the cell (Figure $2 \mathrm{c}, \mathrm{d}$ ). However, no callose accumulation was observed on the wall of aposporic initial cell in the any course of development.

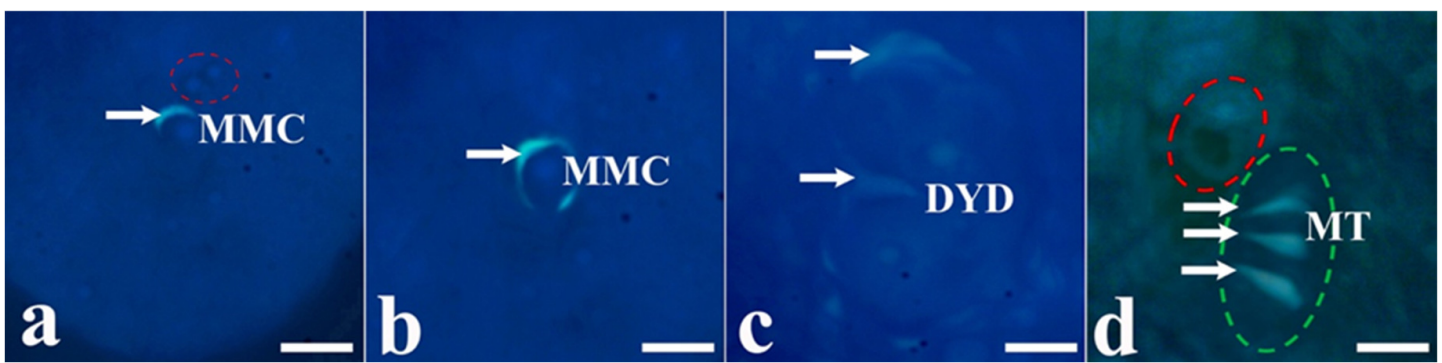

Figure 2. Callose depositions during formation of sexual and apomictic embryo sacs in C. tanacetifolia a Callose accumulation (arrow) on the chalazal pole of megaspore mother cell and no callose accumulation around the aposporic initial cell (into the red circle), b Megaspore mother cell surrounded by callose (arrow), c Callose accumulation (arrow) on the transverse wall of dyad cell, $\mathrm{d}$ Callose accumulation (arrows) on the transverse wall separating each of the tetrad cells (into the green circle) and no callose accumulation around the vacuolated aposporic initial cell (into the red circle). MMC: Megaspore mother cell, DYD: Dyad cells, MT: Megaspore tetrad. Bar: $10 \mu \mathrm{m}$.

\section{Formation of embryo and endosperm}

Embryo and endosperm formation were investigated parallelly with pre-pollination and pollination stages. Egg cell of mature aposporic embryo sac with unreduced chromosome numbered underwent successive mitosis to give rise proembryo, globular embryo, heart shaped embryo, torpedo shaped embryo and mature embryo successively. Because of the flowers had not entered the pollination stage, there were no pollen grains on the stigma of flowers which contain mature 8 nucleated aposporic embryo sac (Figure 3a, b). During proembryo formation, polar nuclei merged to form secondary nucleus (Figure $3 c, d$ ). At this stage, pollination started. There were a lot of pollen grains on stigma, but only a few of them were germinated. However, germinating pollen tubes could not extend into the style (Figure 3e), indicating that embryo develops without fertilization, before the pollen tubes reached the ovule. While embryo was globular, secondary nucleus underwent successive mitosis to form free nucleated endosperm (Figure 3f, g). Currently, there were a lot of germinated pollen grains on the stigma, but there were no pollen tubes extending into the style (Figure $3 \mathrm{~h}$ ). This indicated that endosperm develops autonomically without fertilization. Endosperm which was free nucleated at the beginning of development, continued successive mitosis and transformed into the cellular type 
at the heart-shaped embryo stage or at the beginning of torpedo-shaped embryo (Figure 3i). At this stage, although the pollen tubes were entered into the style, embryo and endosperm already formed (Figure $3 \mathrm{j}$ ). The findings related to embryo and endosperm development with the stages of pollination were presented in Table 2 .

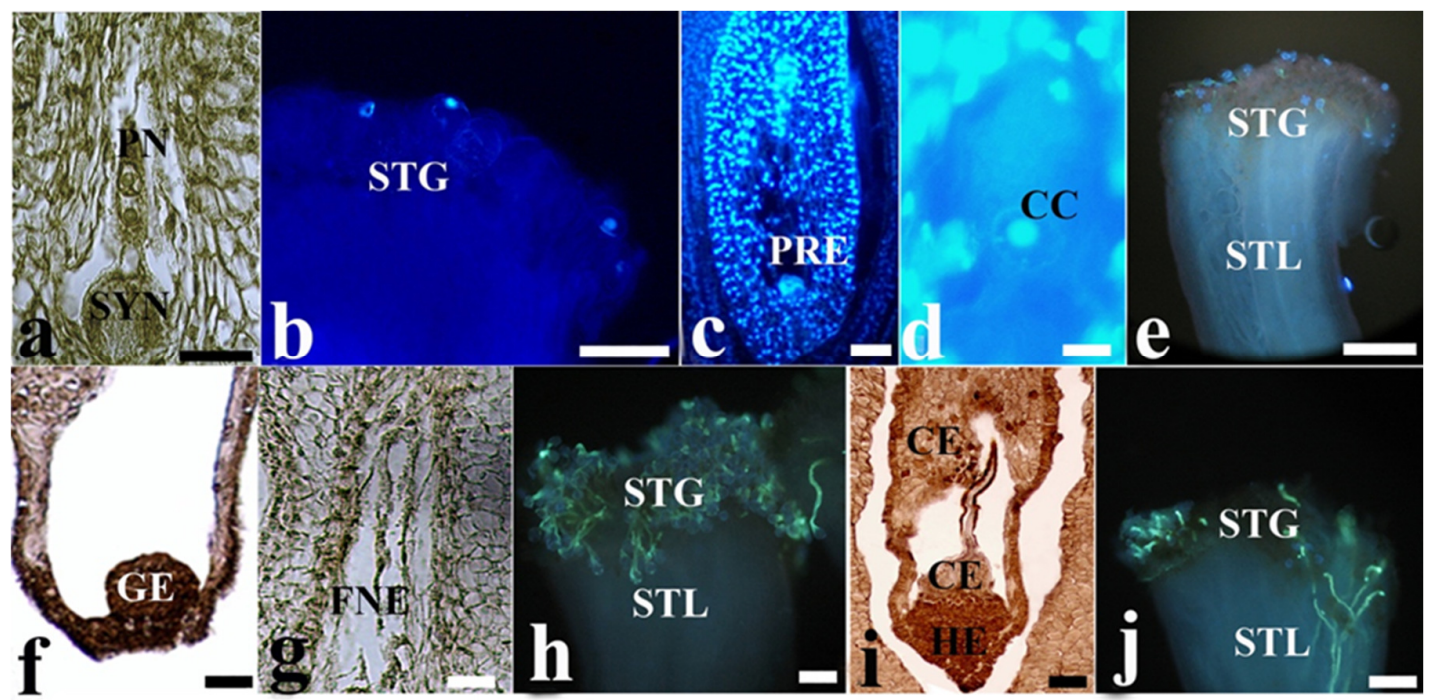

Figure 3. Embryo and endosperm formation in C. tanacetifolia

a Eight nucleated mature aposporic embryo sac, b Aniline Blue stained stigma of the flower containing mature aposporic embryo sac, c DAPI stained proembryo, d DAPI stained Secondary nucleus, e Aniline Blue stained stigma of flower containing proembryo and seconder nucleus, $f$ Globular embryo, $g$ Free nucleated endosperm, $h$ Aniline Blue stained stigma of flower containing globular embryo and free nucleated endosperm, i Heart shaped embryo and cellular endosperm, $\mathbf{j}$ Aniline Blue stained stigma of flower containing heart shaped embryo and cellular endosperm. PN: Polar nuclei, SYN: Synergid cell, STG: Stigma, PRE: Proembryo, CC: Central cell, STL: Style, GE: Globular embryo, FNE: Free nucleated endoperm, CE: Cellular endosperm, HE: Heart shaped embryo. Bar:10 $\mu \mathrm{m}$ (d), $50 \mu \mathrm{m}$ (a, b, c, e, j, f, g, $h, i)$.

Table 2. The comparison of embryo and endosperm formation with the different stages of pollination in C. tanacetifolia

\begin{tabular}{|c|c|c|c|c|}
\hline $\begin{array}{c}\text { Stages of } \\
\text { pollination }\end{array}$ & $\begin{array}{c}\text { Embryo } \\
\text { development stages }\end{array}$ & $\begin{array}{c}\text { Endosperm } \\
\text { development stages }\end{array}$ & Stigma & Style \\
\hline Pre-pollination & $\begin{array}{c}\text { Eight nucleated } \\
\text { mature aposporic } \\
\text { embryo sac }\end{array}$ & Polar nuclei & $\begin{array}{l}\text { No pollen grains on } \\
\text { stigma }\end{array}$ & $\begin{array}{l}\text { No pollen tubes } \\
\text { throughout the style }\end{array}$ \\
\hline \multirow{4}{*}{ Pollination } & Proembryo & $\begin{array}{l}\text { Secondary nucleus } \\
\text { formation }\end{array}$ & $\begin{array}{l}\text { A few germinated pollen } \\
\text { grains with short pollen } \\
\text { tubes on stigma }\end{array}$ & $\begin{array}{l}\text { No pollen tubes } \\
\text { throughout the style }\end{array}$ \\
\hline & Globular embryo & $\begin{array}{c}\text { Free nucleated } \\
\text { endosperm }\end{array}$ & $\begin{array}{c}\text { Germinated pollen grains } \\
\text { on stigma }\end{array}$ & $\begin{array}{c}\text { No pollen tubes } \\
\text { throughout the style }\end{array}$ \\
\hline & $\begin{array}{l}\text { Heart shaped } \\
\text { embryo }\end{array}$ & Cellular endosperm & $\begin{array}{c}\text { Germinated pollen grains } \\
\text { on stigma }\end{array}$ & $\begin{array}{c}\text { Elongation of pollen } \\
\text { tubes throughout the } \\
\text { style }\end{array}$ \\
\hline & $\begin{array}{c}\text { Torpedo shaped } \\
\text { embryo }\end{array}$ & Cellular endosperm & $\begin{array}{c}\text { Germinated pollen grains } \\
\text { on stigma }\end{array}$ & $\begin{array}{c}\text { Elongation of pollen } \\
\text { tubes throughout the } \\
\text { style }\end{array}$ \\
\hline
\end{tabular}




\section{Discussion}

The differentiation time of aposporic initial cells is effective on the reproductive strategy of the plant. They can differentiate before or after the megasporogenesis or after megagametogenesis. Aposporic initial cells differentiate shortly after the MMC formation in aposporic Ranunculus auricomus (Nogler, 1984), Hieracium piloselloides (Koltunow et al., 1998) and Pennisetum squamulatum (Roche et al., 1999), like in C. tanacetifolia. The differentiation of aposporic initial cell after MMC suggests that the onset of sexual development could be a prerequisite for apomixis (Tucker and Koltunow, 2009). Galla et al. (2011) have defined the aposporic initial cells as MMC-like cells and Yao et al. (2007) have reported that aposporic initial cells can be distinguished morphologically from other cells like as MMC. In C. tanacetifolia, aposporic initial cell, which was noted for its similarity to MMC, develops faster than MMC. In Hypericum perforatum L., rapid and remarkable development of aposporic initial cells has also been reported (Galla et al., 2011). In C. tanacetifolia, differantiation of MMC and aposporic initial cell were occurred at pre-anthesis stage.

The number of aposporic initial cells may vary between apomictic species. In Eulaliopsis bianata L., more than one aposporic initial cells differentiate, develop synchronously or asynchronously and $7.9 \%$ of mature ovules contain more than one mature aposporic embryo sac (Li et al., 2011). In Hypericum perforatum L., 1-4 aposporic initial cells develop asynchronously (Galla et al., 2011). Generally, 2 aposporic initial cells differentiated and developed synchronously in C. tanacetifolia.

Although sexual and apomictic development coexisted in $C$. tanacetifolia as well as in aposporic Eulaliopsis bianata L., sexual development ends in the majority of ovules (Li et al., 2011). Tucker et al. (2001) have argued that the termination of sexual development or degeneration of the megaspores are not just a simple mechanical act and Li et al. (2011) have suggested that the termination of sexual development is promoted by a mechanism of aposporic initial cell differentiation. However, sexual and apomictic embryo sacs develop and are located into the same mature ovule in Cenchrus ciliaris L. (Sharma et al., 2014).

In aposporic Pennisetum sp. and Hieracium sp., the atrophy of sexual embryo sac usually occurs at the MMC or megaspore tetrad stages (Koltunow et al., 1998). Sexual embryo sac usually degenerates at dyad or megaspore tetrad stage and the degenerated cells characterized by shrunken and corrupted nuclei in Hypericum

perforatum L. (Galla et al., 2011). This was distinguished in our study as deformations in the atrophied megaspore nuclei. Atrophy of megaspore tetrad in $C$. tanacetifolia was most prominent when the aposporic embryo sac was four nucleated. Also, megaspore tetrad degeneration started and completed at anthesis stage. Although the flowers were at anthesis, pollination had not started yet.

The number of aposporic initial cell's meiotic division is also an important parameter for aposporic species. Although aposporic initial cell underwent 3 successive mitoses to form 8 nucleated mature aposporic embryo sac in C. tanacetifolia, initial cells undergo 2 successive mitoses to give rise 4 nucleated mature aposporic embryo sac in Eulaliopsis binata L. and Cenchrus ciliaris L. (Li et al., 2011; Sharma et al., 2014). In C. tanacetifolia, when 8 nucleated mature aposporic embryo sac was formed, flowers were at post-anthesis stage. Although flowers had entered the post-anthesis, they had not entered the pollination stage.

Although it is known that the callose accumulation model that occurs during megasporogenesis in sexually reproducing plants is effective on in the functional megaspore selection, there are a few studies on the callose accumulation during aposporic embryo sac development (Tucker et al., 2001; Bicknell and Koltunow, 2004; Lersten, 2004; Tucker and Koltunow, 2009; Drews and Koltunow, 2011; Galla et al., 2011; Musial et al., 2015). Callose accumulation pattern in apomictic ovule differs from the sexually developing ovule. For instance, as opposed to the sexually developing ovules, absence of callose accumulation around the MMC has been demonstrated in diplosporous Elymus rectisetus (Carman et al., 1991), Poa nemoralis, Poa palustris (Naumova et al., 1993; 1999) and Tripsacum sp. (Leblanc et al., 1995). Aposporic species, on the contrary of diplosporics, have callose accumulation around the MMC. Although the callose firstly began to accumulate on the chalazal and micropylar wall of MMC in aposporic Hypericum perforatum L., it started to accumulate on the chalazal wall of the MMC in $C$. tanacetifolia. However, the callose completely surrounded the MMC at 
progressive stages and callose accumulated between the dyad cells. Callose accumulation was also seen between the spores of megaspore tetrad. As in C. tanacetifolia, absence of callose accumulation on the wall of aposporic initial cells is shown in aposporic apomictic species like Poa pratensis (Naumova et al., 1993), Panicum maximum (Naumova and Willemse, 1995), Pennisetum sp (Peel et al., 1997), Brachiaria decumbens (Dusi and Willemse, 1999), Hieracium spp (Tucker et al., 2001), H. perforatum (Galla et al., 2011) and Eulaliopsis binata (Li et al., 2011).

Yao et al. (2007) have stated that the development of embryo and endosperm without fertilization in apomictic species may occur due to the problems with sperm entry or problems with female gametogenesis. Unreduced embryo sac is escaped from the fertilization due to the developmental delay in apomictic Malus hupehensis and embryo develops without fertilization. Liu et al. (2014) have defined that phenomenon as 'Female-Late-On-Date'. Its rate is directly related to the apomictic capacities of species and thought to be influenced by environmental temperature during flowering and pollination. In some apomictic species (Pennisetum ciliare), unreduced egg cell is fertilized due to the early pollination and increases the level of polyploidy (Burson et al., 2002). However, there was no delay in the development of female organ in $C$. tanacetifolia, there was a delay in pollination. When eight nucleated embryo sac was formed, pollination had not started yet. Due to the late pollination, the embryo and endosperm formed before the pollen tube reaches the embryo sac. Similarly, aposporous sacs develop endosperm through pseudogamy due to the delayed pollination in Paspalum notatum (Espinoza et al., 2002). An embryological study of aposporic E. binata has revealed that the embryo and endosperm develop autonomously without fertilization (Yao et al., 2007), as in C. tanacetifolia. In diplosporic Chondrilla juncea L. (Koscinska-Pajak and Bednara, 2006), pollen tubes cannot enter synergid cells and thus embryo and endosperm develop autonomously without fertilization. KoscinskaPajak and Bednara (2006) have concluded that this could be related to the absence of filiform apparatus in synergid cells that attract the pollen tubes.

\section{Conclusions}

At pre-anthesis stage, aposporic initial cell differentiated shortly after the megaspore mother cell formation. At anthesis stage, four nucleated aposporic embryo sac was formed while sexual development came to end by atrophy of megaspores completely. At post-anthesis stage, ovule contained only eight nucleated aposporic embryo sac. Callose did not accumulate around the aposporic initial cell in any developmental stage. Pollination started shortly after the proembryo formation. Pollen tubes were delayed in reaching the ovary and embryo and endosperm developed without fertilization.

\section{Authors' Contributions}

Conceptualization: AÇG and MÜ; Data curation: AÇG; Formal analysis: AÇG and MÜ; Investigation: AÇG and MÜ; Methodology: AÇG; Project administration: MÜ; Resources: AÇG and MÜ; Supervision: MÜ; Validation: AÇG and MÜ; Visualization: AÇG and MÜ; Writing - original draft: AÇG and MÜ; Writing - review and editing: AÇG and MÜ. All authors read and approved the final manuscript.

\section{Acknowledgements}

This work was supported by the Research Foundation of Marmara University (BAPKO no. FEN-CDRP-120514-0169). 


\section{Conflict of Interests}

The authors declare that there are no conflicts of interest related to this article.

\section{References}

Bicknell RA, Koltunow AM (2004). Understanding apomixis: recent advances and remaining conundrums. The Plant Cell 16:228-245. https://doi.org/10.1105/tpc.017921

Burson BL, Hussey MA, Actkinson JM, Shafer GS (2002). Effect of pollination time on the frequency of 2+ fertilization in apomictic Buffelgrass. Crop Science 42(4):1075-1080. https://doi.org/10.2135/cropsci2002.1075

Campbell CS, Evans RC, Morgan DR, Dickinson TA, Arsenault MP (2007). Phylogeny of subtribe Pyrinae (formerly the Maloideae, Rosaceae): limited resolution of a complex evolutionary history. Plant Systematic and Evolution 266(1):119-145. https://doi.org/10.1007/s00606-007-0545-y

Carman JG, Crane CF, Riera-Lizarazu O (1991). Comparative histology of cell walls during meiotic and apomeiotic megasporogenesis in two hexaploid Australasian Elymus species. Crop Science 31(6):1527-1532. https://doi.org/10.2135/cropsci1991.0011183X003100060029X

Drews GN, Koltunow AMG (2011). The female gametophyte. The Arabidopsis Book 9:e0155. https://doi.org/10.1199/tab.0155

Dusi DMA, Willemse MTM (1999). Activity and localization of sucrose synthase and invertase in ovules of sexual and apomictic Brachiaria decumbens. Protoplasma 208:173-185. https://doi.org/10.1007/BF01279088

Espinoza F, Pessino SC, Quarin CL, Valle EM (2002). Effect of pollination timing on the rate of apomictic reproduction revealed by RAPD markers in Paspalum notatum. Annals of Botany 89(2):165-170. https://doi.org/10.1093/aob/mcf024

Feder N, O’Brien TP (1968). Plant microtechnique: Some principles and new methods. American Journal of Botany 55(1):123-142. https://doi.org/10.1002/j.1537-2197.1968.tb06952.x

Fisher DB, Jensen WA, Ashton ME (1968). Histochemical studies of pollen: Storage pockets in the endoplasmic reticulum. Histochemie 13:169-182. https://doi.org/10.1007/BF00266578

Galla G, Barcaccia G, Schallau A, Molins MP, Bäumlein H, Sharbel TF (2011). The cytohistological basis of apospory in Hypericum perforatum L.. Sexual Plant Reproduction 24(1):47-61. https://doi.org/10.1007/s00497-010$0147-7$

Hojsgaard D, Hörandl E (2019). The rise of apomixis in natural plant populations. Frontiers in Plant Science 10:358. https://doi.org/10.3389/fpls.2019.00358

Kenrick J, Knox RB (1985). Self-incompatibility in the nitrogen-fixing tree, Acacia retinodes: quantitative cytology of pollen tube growth. Theoretical and Applied Genetics 69(5-6):481-488.

Khan YJ, Choudhary R, Tyagi H, Singh AK (2015). Apomixis: The molecular perspectives and its utilization in crop breeding. Journal of AgriSearch 2(3):153-161.

Koltunow AM, Johnson SD, Bicknell RA (1998). Sexual and apomictic development in Hieracium. Sexual Plant Reproduction 11:213-230. https://doi.org/10.1007/s004970050144

Koscinska-Pajak M, Bednara J (2006). Unusual microtubular cytoskeleton of apomictic embryo sac of Chondrilla juncea L.. Protoplasma 227:87-93. https://doi.org/10.1007/s00709-006-0147-5

Kumar S (2017). Epigenetic control of apomixis: a new perspective of an old enigma. Advances in Plants and Agriculture Research 7(243):10-15406. https://doi.org/10.15406/apar:2017.07.00243

Leblanc O, Peel MD, Carman JG, Savidan Y (1995). Megasporogenesis and megagametogenesis in several Tripsacum species (Poaceae). American Journal of Botany 82:57-63. https://doi.org/10.1002/j.1537-2197.1995.tb15649.x

Lersten NR (2004). Flowering Plant Embryology. Blackwell Publishing Ames, USA.

Li JJ, Liu L, Ouyang YD, Yao JL (2011). Sexual reproduction development in apomictic Eulaliopsis binata (Poaceae). Genetics and Molecular Research 10(4):2326-2339. https://doi.org/10.4238/2011.October:5.3

Liu DD, Fang MJ, Dong QL, Hu DG, Zhou LJ, Sha GL, ... Hao YJ (2014). Unreduced embryo sacs escape fertilization via a 'female-late-on-date' strategy to produce clonal seeds in apomictic crabapples. Scientia Horticulturae 167:76-83. https://doi.org/10.1016/j.scienta.2013.12.035 
Musial K, Koscinska-Pajak M (2013). Ovules anatomy of selected apomictic taxa from Asteraceae family. Modern Phytomorphology 3:35-38.

Musial K, Koscinska-Pajak M, Antolec R, Joachimiak AJ (2015). Deposition of callose in young ovules of two Taraxacum species varying in the mode of reproduction. Protoplasma 252(1):135-144. https://doi.org/10.1007/s00709014-0654-8

Naumova T, Nijs APM, Willemse MTM (1993). Quantitative analysis of aposporous parthenogenesis in Poa pratensis genotypes. Acta Botanica Neerlandia 42(3):299-312. https://doi.org/10.1111/j.1438-8677.1993.tb00707.x

Naumova T, Osadtchiy JV, Sharma VK, Dijkhuis P, Ramulu KS (1999). Apomixis in plants: structural and functional aspects of diplospory in Poa nemoralis and Poa palustris. Protoplasma 208:186-195. https://doi.org/10.1007/BF01279089

Naumova T, Willemse MTM (1995). Ultrastructural characterization of apospory in Panicum maximum. Sexual Plant Reproduction 8(4):192-204. https://doi.org/10.1007/BF00228937

Nogler GA (1984). Gametophytic Apomixis, Embryology of Angiosperms. Springer, New York.

Peel MD, Carman JG, Leblanc O (1997). Megasporocyte callose in apomictic buffelgrass, Kentucky bluegrass, Pennisetum squamulatum Fresen, Tripsacum L., and weeping lovegrass. Crop Science 37(3):724-732. https://doi.org/10.2135/cropsci1997.0011183X003700030006x

Priyadarshan PM (2019). Plant breeding: Classical to Modern. Springer, Singapore.

Robertson A, Rich TCG, Allen AM, Houston L, Roberts C, Bridle JR, ... Hiscock SJ (2010). Hybridization and polyploidy as drivers of continuing evolution and speciation in Sorbus. Molecular Ecology 19(8):1675-1690. https://doi.org/10.1111/j.1365-294X.2010.04585.x

Roche D, Cong P, Chen Z, Hanna WW, Gustine DL, Sherwood RT, Ozias-Akins P (1999). An apospory-specific genomic region is conserved between Buffelgrass (Cenchrus ciliaris L.) and Pennisetum squamulatum Fresen. The Plant Journal 19(2):203-208. https://doi.org/10.1046/j.1365-313x.1999.00514.x

Sass JE (1958). Botanical microtechnique. Iowa State University Press Ames, USA.

Schweizer D (1976). Reverse fluorescent chromosome banding with chromomycin and DAPI. Chromosoma 58(4):307324. https://doi.org/10.1007/BF00292840

Sharma R, Geeta R, Bhat V (2014). Asynchronous male/female gametophyte development in facultative apomictic plants of Cenchrus ciliaris (Poaceae). South African Journal of Botany 91:19-31. https://doi.org/10.1016/j.sajb.2013.10.012

Tang Q, Zang G, Zhao L, Cheng C, Dong Z, Gao C (2016). Embryological and genetic evidence of amphimixis and apomixis in Boehmeria tricuspis. Journal of Plant Biology 59(2):114-120. https://doi.org/10.1007/s12374-0160518-1

Tucker MR, Koltunow AMG (2009). Sexual and asexual (apomictic) seed development in flowering plants: molecular, morphological and evolutionary relationships. Functional Plant Biology 36:490-504. https://doi.org/10.1071/FP09078

Tucker MR, Paech NA, Willemse MT, Koltunow AM (2001). Dynamics of callose deposition and $\beta$-1, 3-glucanase expression during reproductive events in sexual and apomictic Hieracium. Planta 212(4):487-498. https://doi.org/10.1007/s004250000445

Uzun M, Kaya A (2016). Ethnobotanical research of medicinal plants in Mihalgazi (Eskişehir, Turkey). Pharmaceutical Biology 54(12):2922-2932. https://doi.org/10.1080/13880209.2016.1194863

Yao JL, Zhou Y, Hu CG (2007). Apomixis in Eulaliopsis binata: characterization of reproductive mode and endosperm development. Sexual Plant Reproduction 20(3):151-158. https://doi.org/10.1007/s00497-007-0051-y

Zhang Y, Wang C, Wang K (2020). Research advances on plant synthetic apomixis. Chinese Science Bulletin 65(27):2998-3007. https://doi.org/10.1360/TB-2020-0209 
OPEN ACCESS

(c) (9)

The journal offers free, immediate, and unrestricted access to peer-reviewed research and scholarly work. Users are allowed to read, download, copy, distribute, print, search, or link to the full texts of the articles, or use them for any other lawful purpose, without asking prior permission from the publisher or the author.

License - Articles published in Notulae Scientia Biologicae are Open-Access, distributed under the terms and conditions of the Creative Commons Attribution (CC BY 4.0) License.

() Articles by the authors; SHST, Cluj-Napoca, Romania. The journal allows the author(s) to hold the copyright/to retain publishing rights without restriction. 